\title{
Effect of different mulching materials on weed dynamics and yield of direct seeded rice in Chitwan, Nepal
}

\author{
R Gaire, KR Dahal, and LP Amgain \\ Institute of Agriculture and Animal Sciences, Rampur, Chitwan, Nepal
}

\begin{abstract}
An experiment was carried out at farmers' field to compare the effects of live mulches and herbicide on weed growth and dynamics, yield, and economic performance of direct seeded rice under humid sub-tropical condition at Phulbari, Chitwan in 2009. The experiment was conducted in Randomized Complete Block Design with eight treatments and three replications. The treatments consisted of i) control, ii) three hand weeding, iii) herbicide application (bispyribac sodium @ $80 \mathrm{ml} / \mathrm{ha}$ ) + one hand weeding, iv) wheat straw mulch@5t/ha + one hand weeding, v) Eupatorium mulch@5t/ha + one hand weeding, vi) brown manuring with Sesbania aculeata@30 kg/ha, vii) brown manuring with Sesamum indicum @ 2kg/ha, and viii) brown manuring with Crotolaria juncea@30 kg/ha. Weed dry matter accumulation was significantly lower with herbicide application $\left(1.15 \mathrm{~g} / \mathrm{m}^{2}\right)$ than wheat straw mulch $\left(6.75 \mathrm{~g} / \mathrm{m}^{2}\right)$. The treatments with brown manuring and Eupatorium mulch were found to be equally effective in suppressing the weed growth by reducing both dry matter content and weed density. Application of Eupatorium mulch one day after sowing produced significantly higher grain yield $(3.5 \mathrm{t} / \mathrm{ha})$ than control $(1.77 \mathrm{t} / \mathrm{ha})$, Sesamum brown manuring $(2.97 \mathrm{t} / \mathrm{ha})$ and wheat straw mulch $(2.83 \mathrm{t} / \mathrm{ha})$. Yield attributes like effective tillers $/ \mathrm{m}^{2}$, panicle length and panicle weight were positively correlated with grain yield $(\mathrm{r}=0.540,0.705,0.531$ and 0.613 respectively). The net profit (Rs. $63.17 \times 1000 /$ ha) obtained from the treatment with Eupatorium mulch was higher than other tested treatments. Eupatorium mulch and herbicide application recorded equal benefit cost ratio of 2.4. Cultivation of direct seeded rice with the application of Eupatorium mulch or brown manuring (BM) of Sesamum was found effective for increasing yield and net returns in humid subtropical condition of Chitwan. Live mulching could be an eco-friendly weed control options in DSR. The BM option also provides crop residue for the addition of organic matter. This result suggests that $\mathrm{BM}$ is a potential alternative of herbicide application. Either mulching with Eupatorium and wheat straw or growing of Sesbania and Crotolaria as BM with rice up to 30 DAS are advisable to increase productivity with reduced cost of production at Chitwan and similar condition.
\end{abstract}

Key words : brown manuring, direct seeded rice, live mulch, weed dynamics

\section{Introduction}

Rice is grown by transplanting one-month old seedlings into the puddled soil for increasing fertilizer efficiency and minimizing weed population at the initial stage. But, this practice increases the cost of cultivation (Giri, 1996) with potential loss of farm income (Tripathi et al., 2004). Moreover, it has been realized that continuous puddling degrades natural resources like soil and water (Hobbs, 2003). It is estimated that world's per capita availability of water, about $85 \%$ of which is used in agriculture, is decreasing over the years. Balasubramanian et al. (2000) reported that the water availability was declined by $60 \%$ from 1950 to 1990 . Water scarcity threatens the sustainability of irrigated rice ecosystems. Due to water scarcity, it may no longer be feasible for 
farmers to undertake wet cultivation and flood fields to ensure good crop yield (Johnson and Mortimer, 2005). Similarly, the increasing cost of labor threatens the sustainability of transplanted rice within the rice-wheat system in the Indo-Gangetic plains. The labor requirement for transplanted rice (nursery and transplanting) is approximately 50 person days/ha in comparison to 37 person days/ha for drill or wet seeded rice (Mann et al., 2007; FAO, 2010). In comparison to transplanted rice direct seeded rice also minimizes the emissions of methane gas. With the development of resource conserving technologies, direct seeding is being emerged as a viable alternative to transplanted rice (Tripathi et al., 2004). However, the main problem of direct seeded rice (DSR) is the weed infestation, which causes grain yield loss up to 90 percent (Rehman et al., 2007). Maity and Mukherjee (2008) reported that uncontrolled weeds reduce the grain yield by $96 \%$ in dry DSR, $61 \%$ in wet DSR and $40 \%$ in transplanted rice.

The longer weed-free periods, up to 70 days, after the emergence of seeds contributes increasing rice yield. The growth of weeds emerged thereafter is suppressed by the crop (Fischer et al., 1993). The slow initial growth of DSR under moisture stress condition and favorable environment for the growth of wide spectrum of weeds is the main reason of reduced productivity of rain-fed crop. Therefore, effective weed management is essential for higher productivity of direct-seeded rice.

Hand weeding is the most popular method of removing weeds in Nepal and in the developing world. Besides hand weeding, a number of herbicides have been developed and tested for direct seeded rice around the world. The effects of herbicides, such as, butachlor, thiobencarb, pendimethalin, oxyfluoren, propanil, quinclorac, ioxynil, 2, 4-D, and $\mathrm{Na}$ bispyribac have been tested in direct seeded rice in the past. Mulching is another technique to reduce weed problems in direct seeded unpuddled rice. Mulching helps to maintain optimum surface soil moisture for germination and rooting of the crop, protects seeds from birds, and helps controlling weeds. Organic mulch, such as straw, hay, dry sugarcane leaves, FYM, rice hulls, saw dust and bark dust provides stronger mechanical barriers to all kinds of germinating weeds. Singh et al. (2007) reported that the density of grassy weeds was low in the rice field mulched at all stages of crop growth. Gurung (2006) reported that weed infestation was significantly higher in no mulch plot $\left(56.95 \mathrm{~g} / \mathrm{m}^{2}\right)$ than in the mulched plot $\left(38.59 \mathrm{~g} / \mathrm{m}^{2}\right)$. Brown manuring (BM) is another method of controlling weeds in DSR. Brown manuring is simply a no-till version of green manuring, in which selective herbicide 2,4-D (a) 400-500 g/ha is applied to knockdown and desiccate the BM materials like Sesbania nearly at blooming (30-40 days) stage. Co-culturing Sesbania and rice is a common practice throughout the world, but co-culturing Crotolaria, Sesamum, etc. have not been tested so far.

Brown manuring helps smothering weeds, conserving moisture and adding about $15 \mathrm{~kg} \mathrm{~N} / \mathrm{ha}$ without adding much on cost of production. A lower broad-leaved weed density and dry weight were observed with Sesbania and other brown manuring species than the surface mulch. Intercropping of brown manuring crops with rice reduced weed densities by about 40-50 \% (Rehman et al., 2007). Singh et al. (2007) reported that application of wheat residue mulch at $4 \mathrm{t} / \mathrm{ha}$ and Sesbania intercropping for 30 days were equally effective in controlling weeds in dry-seeded rice. The facultative weed Eupatorium has been reported a good source of organic matter and weed suppressor for several upland crops including DSR in Himachal Pradesh (Acharya et al., 1998). Since not much works have been done in this field, this research is designed to address the problem of making DSR popular among farmers with the objective of evaluating the effect of different live mulches and BM in controlling weeds and enhancing rice productivity. 


\section{Materials and methods}

A farmer's field experiment was conducted to see the effects of live mulches and other weed management practices on weed dynamics, crop yield, and economic performance of direct seeded rice (Cv. Ram Dhan) under humid sub-tropical condition at Phulbari, Chitwan in 2009. The experiment was conducted on slightly acidic ( $\mathrm{pH} 5.2$ ) sandy loam soil. The soil was low in available $\mathrm{N}(0.18 \%)$, high in available phosphorus $(59.1 \mathrm{~kg} / \mathrm{ha})$, and low in available potash $(153 \mathrm{~kg} / \mathrm{ha})$.

The experiment was conducted in Randomized Complete Block Design (RCBD) with eight treatments and three replications. The treatments consisted of 1) control, 2) three hand weeding, 3) herbicide application (bispyribac sodium @ $80 \mathrm{ml} / \mathrm{ha}$ ) + one hand weeding, 4) wheat straw mulch @ 5t/ha + one hand weeding, 5) Eupatorium mulch @ 5t/ha + one hand weeding, 6) Brown manuring (BM) with Sesbania aculeata@30 kg/ha, 7) Brown manuring with Sesamum indicum @ 2 kg/ha, and 8) Brown manuring with Crotolaria juncea@30 kg/ha. Rice was sown in line with Chinese power tiller keeping rows $15 \mathrm{~cm}$ apart. The seed rate was $25.0 \mathrm{~kg} / \mathrm{ha}$. Sowing of rice seeds was done in plots of $6.5 \mathrm{~m} \times 5.5 \mathrm{~m}\left(37.75 \mathrm{~m}^{2}\right)$ size. Two plots were separated by a bund of $0.5 \mathrm{~m}$ width and replications were separated by a bund of one $\mathrm{m}$ width.

The area, where research site was located, received about $1485 \mathrm{~mm}$ rainfall during the entire crop growth period. The average relative humidity for that duration was $85.20 \%$. The crop was fertilized with $120.80 .60 \mathrm{~kg} \mathrm{NPK} /$ ha through Urea, Di-ammonium phosphate (DAP) and Muriate of potash (MOP). Fifty percent of the N, and whole $\mathrm{P}$ and $\mathrm{K}$ was used as basal dose and the remaining $50 \%$ of $\mathrm{N}$ was top dressed, half at maximum tillering stage (35 DAS) and another half at panicle initiation stage (60 DAS). Before sowing, rice seeds were soaked in cold water for 12 hours and treated with Bavistin@2 g/kg seed. These treated seeds were sown in the field with Chinese seed drill. From the experimental site, $10 \mathrm{~m}^{2}$ area at the centre was taken as net plot rows for harvesting and remaining 4 rows each on both sides of the net plot were used for biometrical and phenological observations. Major weeds in the rice field were identified. Weed density and dry weight of these weeds were measured especially up to maximum vegetative stage. Effective tillers $/ \mathrm{m}^{2}$, number of grains/panicle, thousand seed weight, grain and straw yields were recorded during the experimentation. Statistical analysis of the data was carried out by MSTAT- C package, and correlation and regression analysis was done by using Minitab. Mean was separated by performing analysis of variance (ANOVA) at 5\% significance level (Gomez and Gomez, 1984).

\section{Results and discussion}

\section{Weed species, weed density, weed dry matter content, and their relations with rice yield}

Main weed species found in the experimental sites were categorized into two groups. Broad leaved weeds, such as Gandhe (Ageratum conyzoides), Lunde (Amaranthus species), Kane (Commelina diffusa), Bhringraj (Eclipta prostrate), Jwane (Fimbristylis miliace) were kept in the first group. Grasses and sedges, such as Dubo (Cynodon dactylon), Banso (Digitaria adcendens), Sawa (Echinochloa colona) Kade sawa (Echinochloa crusgalli), Madilo (Ischaemum rugosum), Godhe dubo (Paspalum distichum), and Sedges (Cyperus iria, Cyperus difformis) were kept in the second group. The result showed significant effect of weed management on weed count. Significantly 
higher positive correlation $(r=0.982)$ was observed between weed density and weed dry mater at 45 DAS (Table 1, and Fig 1).

Table 1. Correlation coefficient among yield attributing characters, weed dry matter accumulation at $45 \mathrm{DAS}\left(\mathrm{g} / \mathrm{m}^{2}\right)$, and straw and grain yields in DSR at Phulbari VDC, Chitwan in 2009

\begin{tabular}{|c|c|c|c|c|c|c|c|c|}
\hline $\begin{array}{l}\text { Para- } \\
\text { meter }\end{array}$ & $\begin{array}{c}\text { WM } 45 \\
\text { DAS }\end{array}$ & FPP & ET & PL & PW & GPP & TGW & SY \\
\hline \multicolumn{9}{|l|}{ WM 45} \\
\hline DAS & & & & & & & & \\
\hline FPP & $-0.584 * *$ & & & & & & & \\
\hline ET & $-0.666^{* *}$ & $0.838 * *$ & & & & & & \\
\hline PL & $-0.538 * *$ & $0.455^{*}$ & $0.456^{*}$ & & & & & \\
\hline PW & $-0.630 * *$ & 0.324 & $0.407 *$ & $0.837 * *$ & & & & \\
\hline GPP & $-0.420 *$ & 0.311 & 0.282 & $0.708 * *$ & $0.723 * *$ & & & \\
\hline TGW & 0.106 & 0.272 & 0.033 & 0.013 & -0.067 & -0.041 & & \\
\hline SY & $-0.795^{* *}$ & $0.618 * *$ & $0.552 * *$ & 0.286 & 0.386 & 0.318 & 0.28 & \\
\hline GY & $-0.860 * *$ & $0.540 * *$ & $0.705^{* *}$ & $0.531 * *$ & $0.613^{* *}$ & 0.354 & -0.114 & $0.693 * *$ \\
\hline
\end{tabular}

Effect of weed density at 45 DAS on grain yeild of DSR

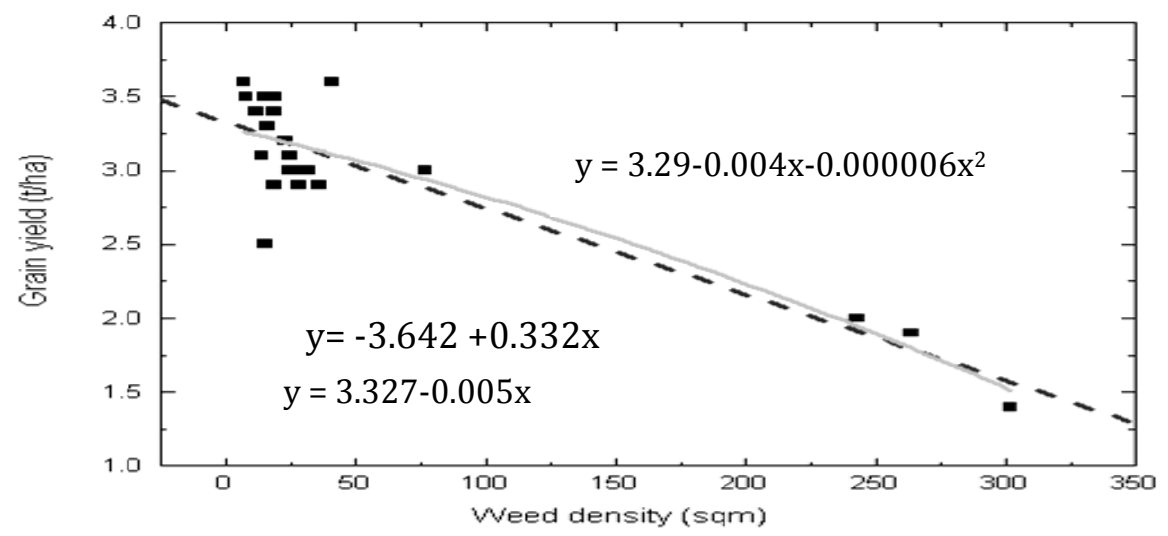

Figure 1. The relationship between weed density at 45 DAS and grain yield of DSR at Phulbari, Chitwan

Weed management practices adopted in all treatments significantly reduced the weed density and weed dry matter as compared to control (Table 2). Herbicide application was found most effective to suppress weed growth in terms of density and dry matter accumulation at all stages of crop growth. The weed density was found maximum at early growth stage of crop (15 DAS) in all 76 
treatments except control, but declined remarkably at 30 DAS and 45 DAS. The result showed that wheat straw mulch and Eupatorium mulch were found most effective, and BM was found least effective in controlling weed density at early stages (15 and 30 DAS) of crop growth.

Table 2. Effect of mulching materials on weed density (no. of weeds $\left./ \mathrm{m}^{2}\right)$ and dry weight $\left(\mathrm{g} / \mathrm{m}^{2}\right)$ in DSR at Gopalgunj, Phulbari VDC, Chitwan in 2009

\begin{tabular}{|c|c|c|c|}
\hline Treatments & $15 \mathrm{DAS}$ & $30 \mathrm{DAS}$ & 45 DAS \\
\hline Control ( $\left.\mathrm{T}_{1}\right)$ & $303.3^{\mathrm{ab}}\left(16.2^{\mathrm{a}}\right)$ & $199.0^{\mathrm{a}}\left(86.7^{\mathrm{a}}\right)$ & $269.7^{\mathrm{a}}\left(88.2^{\mathrm{a}}\right)$ \\
\hline 3 hand weeding $\left(\mathrm{T}_{2}\right)$ & $281.0^{\mathrm{ab}}\left(12.5^{\mathrm{ab}}\right)$ & $47.0^{\mathrm{c}}\left(5.5^{\mathrm{e}}\right)$ & $20.3^{\mathrm{b}}\left(3.2^{\mathrm{bc}}\right)$ \\
\hline $\begin{array}{l}\text { Herbicide bispyribac application } \\
\left(\mathrm{T}_{3}\right)\end{array}$ & $223.3^{\mathrm{ab}}\left(15.6^{\mathrm{a}}\right)$ & $41.3^{\mathrm{c}}\left(25.9^{\mathrm{d}}\right)$ & $11.7^{\mathrm{b}}\left(1.2^{\mathrm{c}}\right)$ \\
\hline Wheat straw mulch $\left(\mathrm{T}_{4}\right)$ & $157.3^{b}\left(5.9^{c}\right)$ & $93.7^{\mathrm{bc}}\left(41.4^{\mathrm{cd}}\right)$ & $41.3^{\mathrm{b}}\left(6.8^{\mathrm{b}}\right)$ \\
\hline Eupatorium mulch $\left(\mathrm{T}_{5}\right)$ & $246.7^{\mathrm{ab}}\left(7.9^{\mathrm{bc}}\right)$ & $146.7^{\mathrm{ab}}\left(66.6^{\mathrm{b}}\right)$ & $26.0^{\mathrm{b}}\left(3.9^{\mathrm{bc}}\right)$ \\
\hline BM Sesbania (T) & $331.7^{\mathrm{a}}\left(17.8^{\mathrm{a}}\right)$ & $137.7^{\mathrm{ab}}\left(27.9^{\mathrm{d}}\right)$ & $23.3^{\mathrm{b}}\left(4.0^{\mathrm{bc}}\right)$ \\
\hline BM Sesamum ( $\left.\mathrm{T}_{7}\right)$ & $263.3^{\mathrm{ab}}\left(13.4^{\mathrm{ab}}\right)$ & $99.7^{\mathrm{bc}}\left(53.7^{\mathrm{bc}}\right)$ & $23.0^{\mathrm{b}}\left(4.2^{\mathrm{bc}}\right)$ \\
\hline BM Crotolaria $\left(\mathrm{T}_{8}\right)$ & $293.7^{\mathrm{ab}}\left(14.8^{\mathrm{a}}\right)$ & $151.7^{\mathrm{ab}}\left(59.6^{\mathrm{b}}\right)$ & $22.3^{\mathrm{b}}\left(4.7^{\mathrm{bc}}\right)$ \\
\hline $\operatorname{LSD}(=0.05 \%)$ & $144.3(5.53)$ & $73.61(16.50)$ & $29.38(4.90)$ \\
\hline
\end{tabular}

Figures in parentheses indicate the weed dry matter $\left(\mathrm{g} / \mathrm{m}^{2}\right)$. Means separated by DMRT and columns represented with same letters are not significant at $5 \%$ level of significance.

\section{Yield and yield attributes of rice}

A wide variation was observed between treatments in yield attributes, such as effective tillers $/ \mathrm{m}^{2}$ and grains/panicle, but statistically the results of the use of Eupatorium mulch, and brown manuring with Crotolaria are not significantly different. Similarly, significant difference was not observed in thousand seed weight, which ranged from 22.63 to $24.33 \mathrm{~g}$, depending upon the weed management practices (Table 3). The observed result agreed with Hasanuzzaman et al. (2008) who reported that thousand seed weight remained statistically unchanged in different weed management practices. 
Table 3. Effect of mulching materials on yield attributing characters and grain and straw yields of DSR at Gopalgunj, Phulbari VDC, Chitwan in 2009

\begin{tabular}{|c|c|c|c|c|c|}
\hline Treatment & $\begin{array}{l}\text { Effective } \\
\text { tillers } / \mathrm{m}^{2}\end{array}$ & $\begin{array}{l}\text { Grains/ } \\
\text { panicle }\end{array}$ & $\begin{array}{l}1000 \text { seed } \\
\text { weight }(\mathrm{g})\end{array}$ & $\begin{array}{l}\text { Grain yield } \\
(\mathrm{t} / \mathrm{ha})\end{array}$ & $\begin{array}{c}\text { Straw } \\
\text { yield }(\mathrm{t} / \mathrm{ha})\end{array}$ \\
\hline Control ( $\left.\mathrm{T}_{1}\right)$ & $96.67^{b}$ & $186.3^{b}$ & $23.82^{\mathrm{a}}$ & $1.77^{\mathrm{c}}$ & $3.17^{\mathrm{d}}$ \\
\hline 3 hand weeding $\left(\mathrm{T}_{2}\right)$ & $143.67^{\mathrm{ab}}$ & $217.3^{\mathrm{ab}}$ & $23.73^{\mathrm{a}}$ & $3.17^{\mathrm{ab}}$ & $4.43^{\mathrm{bc}}$ \\
\hline $\begin{array}{l}\text { Herbicide bispyribac } \\
\text { application }\left(\mathrm{T}_{3}\right)\end{array}$ & $181.67^{\mathrm{a}}$ & $216.0^{\mathrm{ab}}$ & $23.42^{\mathrm{a}}$ & $3.43^{\mathrm{a}}$ & $5.00^{\mathrm{a}}$ \\
\hline $\begin{array}{l}\text { Wheat straw mulch } \\
\left(\mathrm{T}_{4}\right)\end{array}$ & $142.33^{\mathrm{ab}}$ & $239.7^{\mathrm{a}}$ & $24.05^{\mathrm{a}}$ & $2.83^{\mathrm{b}}$ & $4.83^{\mathrm{ab}}$ \\
\hline $\begin{array}{l}\text { Eupatorium mulch } \\
\left(\mathrm{T}_{5}\right)\end{array}$ & $162.67^{\mathrm{a}}$ & $243.0^{\mathrm{a}}$ & $24.33^{\mathrm{a}}$ & $3.50^{\mathrm{a}}$ & $4.77^{\mathrm{ab}}$ \\
\hline BM Sesbania $\left(\mathrm{T}_{6}\right)$ & $172.33^{\mathrm{a}}$ & $198.0^{\mathrm{b}}$ & $22.80^{\mathrm{a}}$ & $3.17^{\mathrm{ab}}$ & $4.83^{\mathrm{ab}}$ \\
\hline BM Sesamum $\left(\mathrm{T}_{7}\right)$ & $171.00^{\mathrm{a}}$ & $197.7^{\mathrm{b}}$ & $23.05^{\mathrm{a}}$ & $2.97^{\mathrm{b}}$ & $4.17^{\mathrm{c}}$ \\
\hline BM Crotolaria $\left(\mathrm{T}_{8}\right)$ & $188.00^{\mathrm{a}}$ & $245.3^{\mathrm{a}}$ & $22.63^{\mathrm{a}}$ & $3.23^{\mathrm{ab}}$ & $4.17^{\mathrm{c}}$ \\
\hline LSD & 48.84 & 33.95 & 2.559 & 0.388 & 0.514 \\
\hline
\end{tabular}

Means separated by DMRT and columns represented with same letters are not significant at 5\% level of significance.

The average grain yield in this experiment was $3.01 \mathrm{t} / \mathrm{ha}$, ranging from $1.77 \mathrm{t} / \mathrm{ha}$ to $3.5 \mathrm{t} / \mathrm{ha}$ (Table 3 ) in different treatments. All other treatments produced significantly higher grain yield than the control $(1.67 \mathrm{t} / \mathrm{ha})$. Significantly higher yields were observed in the treatments, in which Eupatorium mulch $(3.5 \mathrm{t} / \mathrm{ha})$ and $\mathrm{Na}$ bispyribac herbicide $(3.43 \mathrm{t} / \mathrm{ha})$ were used. Among the BM treatments, the use of Crotolaria produced relatively higher yield (3.23 t/ha) than others and was at par the use of Na bispyribac. Similarly, the average straw yield observed in the experiment was 4.42 $\mathrm{t} / \mathrm{ha}$ ranging from $3.17 \mathrm{t} / \mathrm{ha}$ to $5.0 \mathrm{t} / \mathrm{ha}$ depending upon the weed management practices. The straw yield with herbicide application was significantly higher $(5.0 \mathrm{t} / \mathrm{ha})$ than three hand weeding $(4.4$ $\mathrm{t} / \mathrm{ha}$ ) and BM treatments except Sesbania BM. This result agrees with the findings of Hasanuzzaman et al. (2008), which stated that herbicide application produced higher straw yield than hand weeding. Sesbania BM produced significantly higher straw yield $(4.8 \mathrm{t} / \mathrm{ha})$ in comparison to Crotolaria BM (4.17 t/ha) and Sesamum BM (4.17 t/ha). The relationships between weed density and weed dry matter at 45 DAS and grain yield of DSR have shown the negative correlation (Table 1 and Fig 2). 


\section{Effect of Weed dry matter on grain yield in DSR}

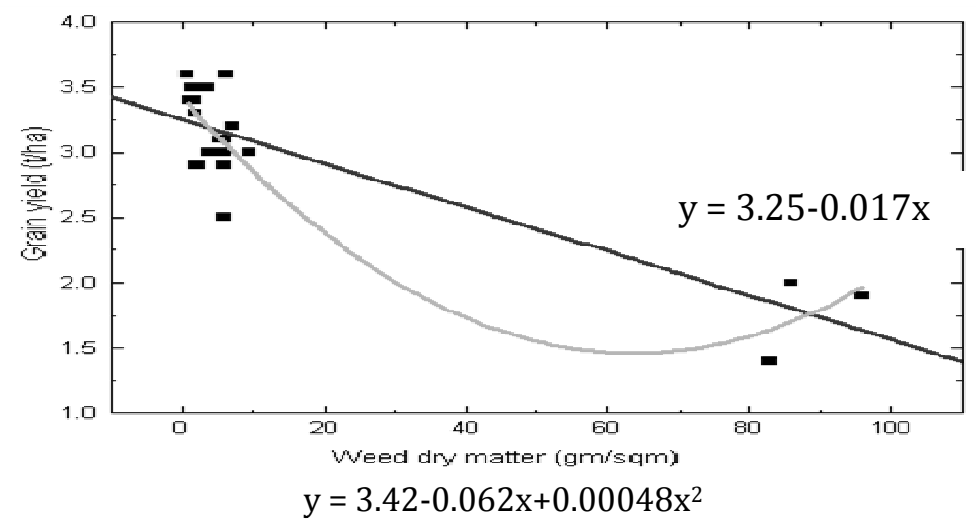

Fig 2. The relationship between weed dry matter at 45 DAS and grain yield of DSR at Phulbari, Chitwan

\section{Economics of DSR}

The economics of various weed management treatments are presented in Table 4. Direct-seeding has the potential to reduce cost. Cost of cultivation was found to vary from Rs. $34.60 \times 1000 / \mathrm{ha}$ (control) to Rs. $50.35 \times 1000$ /ha ( 3 hand weeding). The gross returns of different treatments varied from Rs. $53.68 \times 1000$ /ha to $101.80 \times 1000 /$ ha depending upon different treatments. Eupatorium mulch gave highest gross returns (Rs. $101.80 \times 1000 /$ ha) as compared to all other treatments. Among the BM, Sesbania (Rs. $93.67 \times 1000 /$ ha) and Crotolaria (Rs. $93.33 \times 1000 /$ ha) produced more gross return than Sesamum (Rs. $86.68 \times 1000 /$ ha). The calculation of net return is another parameter of conducting economic analysis in this research. The net return varied from Rs. $19.07 \mathrm{x}$ $1000 /$ ha (control) to Rs. 59.15 x 1000/ha

Table 4. Economic analysis of different treatments as affected by live mulch at farmers' field in Phulbari VDC, Chitwan in 2009

\begin{tabular}{lcccc}
\hline Treatments & $\begin{array}{c}\text { Cost of } \\
\text { cultivation } \\
(\mathbf{x ~ 1 0 0 0 ~ R s / h a )}\end{array}$ & $\begin{array}{c}\text { Gross returns } \\
(\mathbf{x ~ 1 0 0 0} \\
\mathbf{R s} / \mathbf{h a})\end{array}$ & $\begin{array}{c}\text { Net returns } \\
(\mathbf{x 1 0 0 0} \\
\mathbf{R s} / \mathbf{h a})\end{array}$ & $\begin{array}{c}\text { Benefit. } \\
\text { cost ratio }\end{array}$ \\
\hline Control $\left(\mathrm{T}_{1}\right)$ & 34.60 & 53.68 & 19.07 & 1.5 \\
3 hand weeding $\left(\mathrm{T}_{2}\right)$ & 50.35 & 92.47 & 42.12 & 1.8 \\
Bispyribac application $\left(\mathrm{T}_{3}\right)$ & 42.15 & 100.81 & 58.68 & 2.4 \\
Wheat straw mulch $\left(\mathrm{T}_{4}\right)$ & 45.90 & 85.32 & 39.42 & 1.9 \\
Eupatorium mulch $\left(\mathrm{T}_{5}\right)$ & 42.65 & 101.80 & 59.15 & 2.4 \\
BM Sesbania $\left(\mathrm{T}_{6}\right)$ & 41.65 & 93.67 & 52.02 & 2.3 \\
BM Sesamum $\left(\mathrm{T}_{7}\right)$ & 40.06 & 86.68 & 46.61 & 2.2 \\
BM Crotolaria $\left(\mathrm{T}_{8}\right)$ & 41.35 & 93.33 & 51.97 & 2.3 \\
\hline
\end{tabular}


(Eupatorium mulch). All tested treatments were found superior to control in terms of net return. The B. C ratio also gave similar result. This ratio ranged from 1.5 to 2.4. The highest $\mathrm{B}$. C ratio was obtained in Eupatorium mulch and herbicide application (2.4). A higher B.C ratio of BM was found than the wheat straw mulch. Singh et al. (2007) reported that Sesbania as brown manuring was as effective as the mulch in realizing higher economic returns. However, the result of this research suggested that the economic return of brown manuring is higher than wheat straw mulch.

\section{Acknowledgements}

The research was funded by CSISA Chitwan Hub. The authors would like to extend sincere thanks to CSISA and farmer Tara Bastola for providing field for experimentation.

\section{References}

Acharya, CL, OC Kapur and SP Dixit .1998. Moisture conservation for rainfed wheat production with alternative mulches and conservation tillage in hills of north-west India. Soil and Tillage Research 46. 153-163.

Balasubramanian, R, J Krishnarajan and S Ramesh .2000. Economical use of water for directseeded rice. In. Peng, S. and B. Hardy (eds.). Rice research for food security and poverty alleviation. Proceedings of the International Rice Research Conference, Los Banos, Philippines, 31 March-3 April, 2000.

FAO. 2010. Proven technologies for smallholders. Weed management for direct seeded rice. Technology for agriculture.

Fischer, AJ, J Lozano, A Ramirez and Lr Sanint .1993. Yield loss prediction for integrated weed management in direct-seeded rice. International J. of Pest Mgmt. 39(2).175-180.

Giri, GS .1996. The effect of rice culture on subsequence wheat grain yield. R. N. Devkota, E. E. Saari (eds.). In. Proceedings of wheat research reports National Wheat Research Program Siddarthnagar, Bhairawaha. National winter crops technology workshop (September 710, 1995). pp.415-418.

Gomez, KA and AA Gomez (1984). Statistical procedures for agricultural research (2 ${ }^{\text {nd }}$ ed.). John Wiley and Sons, Inc., Singapore.

Gurung, DB .2006. Performance of rice as influenced by planting method, mulch and nitrogen management using leaf color chart (LCC). M. Sc. Thesis submitted to Tribhuvan University, Institute of Agriculture and Animal Science, Rampur, Chitwan.

Hasanuzzaman, M., MO Islam and MS Bapari (2008). Efficacy of different herbicides over manual weeding in controlling weeds in transplanted rice. Australian Journal of Crop Science, 2 (1). 18-24.

Hobbs, P R .2003. Alternatives to puddling and manual transplanting. In RWC- CIMMYT. Addressing Resource Conservation issues in Rice- Wheat System of South Asia. A Resource Book, March 2003. Rice-Wheat consortium for indo-gangetic plains. International wheat and maize improvement centre, New Delhi. pp. 129-140.

Johnson, D E and A M Mortimer .2005. Issues for weed management in direct-seeded rice and the development of decision-support frameworks. In. Workshop on Direct-seeded Rice in the 
Rice-Wheat system of the Indo-Gangetic Plains. 1-2 February .2005. G.B. Pant University of Agriculture \& Technology, Pantnagar, Uttaranchal. India. pp.8.

Maity, S K and P K Mukherjee .2008. Integrated weed management in dry direct seeded rainy season rice. Indian J. Agron. 53 (2). June 2008.

Mann, R A, S Ahmad, G Hassan and M S Baloch .2007. Weed Management in direct seeded rice crop. Pak. J. Weed Sci. Res. 13(3-4). 219-226.

Rehman, H, M Farooq and A Khalid. 2007. Managing weeds in direct seeded rice. DAWN group of newspaper .2007. http.//DAWN.com.

Singh, S R, S Chhokar, R Gopal, J K Ladha, R. K. Gupta, V. Kumar and M. Singh .2007. Integrated weed management. A key to success for direct seeded rice in the Indo-Gangetic Plains. Integrated Crop and Resource Management in the Rice - Wheat system of South Asia. pp. 261-270.

Tripathi, J, M R Bhatta, S Justice and N K Sakya. 2004. Direct seeding. An emerging resource conserving technology for rice cultivation in rice- wheat system. In A. K. Gautam, T. Akhtar, B. Chaudhary, J. Gaire, K. R. Bhatta (eds.). Rice Research in Nepal proceedings of the $24^{\text {th }}$ summer crop workshop June 28-30, 2004. Nepal Agriculture Research Council. National Rice Research Program, Hardinath, Baniniya, Dhanusha .2004. pp.273- 281. 